\title{
Effects of feed supplemented with selenite or Se-yeast on antioxidant enzyme activities in lamb tissues
}

\author{
A. Sobeková ${ }^{1,3}$, K. Holovská ${ }^{1}$, V. Lenártová ${ }^{1}$, K. Holovská Jr¹, \\ P. Javorský ${ }^{2}$, K. Boldižárová ${ }^{2}$, L. Grešáková ${ }^{2}$ and L. Leng ${ }^{2}$ \\ ${ }^{1}$ University of Veterinary Medicine \\ 04181 Košice, Slovak Republic \\ ${ }^{2}$ Institute of Animal Physiology, Slovak Academy of Sciences \\ 04001 Košice, Slovak Republic
}

(Received 13 March 2006; revised version 12 June 2006; accepted 6 November 2006)

\begin{abstract}
The activities of antioxidant enzymes: superoxide dismutase (SOD), catalase (CAT), glutathione peroxidase (GSHPx), glutathione-S-transferase (GST) and glutathione reductase (GR) were examined in liver, kidney cortex and heart tissues of lambs fed diets supplemented with inorganic (sodium selenite) and an organic (Se-yeast) form of selenium. Additional selenium resulted in a significant increase of the Se content in the examined tissues in both supplemented groups. The activities of GSHPx, CAT in the liver as well as of CAT, GST and SOD in the kidney cortex were significantly lower in the Se-yeast supplemented group when compared with both the control and selenite-fed groups. In the heart, the activities of all of the assayed enzymes increased in both supplemented groups. SOD activity was found to be significantly higher in the Se-yeast supplemented group when compared with the selenite group. In addition, two $\mathrm{Cu}, \mathrm{Zn}$-SOD isoenzymes of higher band intensity were generated in this group, probably as a result of oxidative stress, which was also manifested by a significant increase of thiobarbituric acid reactive substances (TBARS). The presented results suggest specific regulation of antioxidant enzyme activities in the tissues of lambs depending on the form of selenium intake.
\end{abstract}

KEY WORDS: lamb, sodium selenite, Se-yeast, superoxide dismutase, glutathione peroxidase, glutathione reductase

\footnotetext{
${ }^{*}$ Supported by Grant Agency VEGA, Grant No. 2/6175/26 and 2/6173/6 and APVT- 51012602

${ }^{3}$ Corresponding author: e-mail: asobekova@hotmail.com
} 


\section{INTRODUCTION}

The major antioxidant function of selenium is achieved through its redox activity when present as selenocysteine in the structure of selenoproteins. In 1973, investigators discovered that the biochemical function of selenium resides in its involvement in the active site of the selenoenzyme GSHPx, which provides a major defense mechanism against lipid peroxidation in the tissues because of its capacity to destroy hydrogen peroxide and organic hydroperoxides (Rotruck et al., 1973). The glutathione peroxidases, and possibly other selenoproteins (selenoprotein $\mathrm{P}$ and selenoprotein $\mathrm{W}$ ), belong to antioxidant proteins (Schrauzer, 2000).

Many organic and inorganic selenium compounds have been investigated as selenium supplements. The selenium forms used in supplements are inorganic selenate and selenite, and organic selenium in the form of selenomethionine, selenocysteine and selenium-enriched yeast. The majority of the total selenium (60$80 \%$ ) in the enriched yeast consists of selenomethionine (Rayman, 2004). In addition to this form, a number of uncharacterized forms exist, but their contribution to total dietary selenium is unknown (Reilly, 1998). Both organic and inorganic sources of selenium are utilized for the synthesis of selenoproteins. Whereas selenium from selenate and selenite may be immediately available for synthetic processes, a varying part of selenium provided as selenomethionine or selenocysteine will be unspecifically deposited in tissue proteins (Wolfram, 1999). Numerous studies have suggested differences in selenium absorption in ruminants and monogastric animals because of the metabolic activity of rumen microorganisms (Hakkarainen, 1993; Wolfram, 1999).

The present study was designed to examine whether and to what extent the antioxidant enzyme activities in tissues of lambs are influenced by the form of selenium added to feed.

\section{MATERIAL AND METHODS}

\section{Animals and diets}

The experiment was carried out on 15 male lambs of the Valaška (meat/milk type) breed divided at the age of four months into 3 groups of 5 animals. For the subsequent five months the animals were housed in individual pens with free access to water and fed pre-weighed daily rations that differed only in the total content and/or form of supplemented selenium. The control group was given the basal diet (BD) with a daily selenium content of $50.6 \mu \mathrm{g} / \mathrm{animal}$ coming only from 
Table 1. The composition of the daily ration of basal diet per lamb and Se intake

\begin{tabular}{lcccc}
\hline Component & $\mathrm{g}$ & $\begin{array}{c}\text { Dry matter } \\
\mathrm{g}\end{array}$ & $\begin{array}{c}\mathrm{Se}, \mu \mathrm{g} \cdot \mathrm{kg}^{-1} \\
\text { of DM }\end{array}$ & $\begin{array}{c}\text { Se intake } \\
\mu \mathrm{g} / \mathrm{day}\end{array}$ \\
\hline Hay & 500 & 440.0 & 61.9 & 27.2 \\
Rapeseed oilmeal & 40 & 36.3 & 166.5 & 6.1 \\
Barley & 300 & 259.0 & 66.8 & 17.3 \\
\hline
\end{tabular}

the natural occurrence of selenium in the dietary components. The composition of the daily ration of BD per lamb and the daily delivery of selenium by $\mathrm{BD}$ is presented in Table 1. The diet for the selenite group of lambs was the same BD plus a selenium supplement of $0.3 \mathrm{mg} \cdot \mathrm{kg}^{-1}$ of dry matter (DM) in the form of $\mathrm{Na}_{2} \mathrm{SeO}_{3}$ resulting in a final daily selenium intake of $278.6 \mu \mathrm{g} / \mathrm{animal}$. The Seyeast group received BD supplemented with $0.3 \mathrm{mg} \mathrm{kg} \mathrm{kg}^{-1}$ of DM of selenium in the form of Se-yeast extract (Sel-Plex, Alltech Inc., USA) giving the same daily selenium intake $(278.6 \mu \mathrm{g} /$ animal $)$ as in selenite group of lambs. The diets for the control and selenite groups were also fortified with adequate amounts of the yeast extract without selenium (NuPro, Alltech Inc., USA) to obtain the same final levels of yeast extract as in the Se-yeast group (daily intake $1.04 \mathrm{~g}$ of NuPro in feed). At the end of the experiment the animals were euthanazied and samples of the liver, kidney cortex, and heart were taken.

Analysis

Pieces of tissues (liver, kidney cortex, and heart) were homogenized in 10 mmol: $\mathrm{L}^{-1}$ Tris-HCl buffer $\mathrm{pH} 8.0$ containing $0.1 \mathrm{mmol}^{-1} \mathrm{Na}_{2} \mathrm{EDTA}$ and $2 \mathrm{mmolL} \mathrm{L}^{-1}$ GSH using an Ultra-Turrax homogenizer. The homogenates $(25 \% \mathrm{w} / \mathrm{v})$ were centrifuged at $105000 \mathrm{~g}$ at $4^{\circ} \mathrm{C}$ for $60 \mathrm{~min}$ and stored at $-60^{\circ} \mathrm{C}$ until used for enzyme assays.

Superoxide dismutase activity (SOD, EC 1.15.1.1) was determined by measuring the inhibition of cytochrome $\mathrm{c}$ reduction using a xanthine/xanthine oxidase $\mathrm{O}_{2}^{-}{ }^{-}$generating system at $550 \mathrm{~nm}$ (Flohé and Ötting, 1984). One unit of SOD activity was defined as the amount of enzyme that causes $50 \%$ inhibition of cytochrome c reduction under the assay conditions. Catalase (CAT, EC 1.11.1.6) was assayed by monitoring the decrease in absorbance of $\mathrm{H}_{2} \mathrm{O}_{2}$ at $240 \mathrm{~nm}$ (Sizer and Beers, 1952). Glutathione peroxidase activity (GSHPx, EC 1.11.1.9) was measured by monitoring the oxidation of $\mathrm{NADPH}+\mathrm{H}^{+}$at $340 \mathrm{~nm}$ as described by Flohé and Günzler (1984) in a coupled assay with glutathione reductase. Cumene hydroperoxide was used as substrate. Glutathione reductase (GR, EC 1.6.4.2) was determined by following the decrease in NADPH $+\mathrm{H}^{+}$absorbance at $340 \mathrm{~nm}$ due to GSSG reduction (Pinto et al., 1984). Glutathione-S-transferase 
(GST, EC 2.5.1.18) was measured by the procedure of Habig and Jacoby (1981) at $30^{\circ} \mathrm{C}$ using as the substrate $\mathrm{CDNB}$ at a final concentration of $1 \mathrm{mmol} \cdot \mathrm{L}^{-1}$; the GSH concentration was $1 \mathrm{mmol} \cdot \mathrm{L}^{-1}$. One unit of enzyme activity (GSHPx, GR and GST) was defined as the amount of enzyme that catalyzes the formation of $1 \mu \mathrm{mol}$ of product per minute under the assay conditions.

Isoelectrofocusing was carried out with PhastSystem equipment; $\mathrm{pI}$ values of SODs were determined in gels with a $\mathrm{pH}$ gradient of 3-9 using isoelectrofocusing calibration kits (Pharmacia). SOD activity was stained in situ using nitroblue tetrazolium, riboflavin and TEMED (Beauchamp and Fridovich, 1971). Two types of SOD were distinguished by soaking the gels with $10 \mathrm{mmol} \mathrm{L}^{-1} \mathrm{KCN}$ : $\mathrm{Cu}, \mathrm{Zn}-\mathrm{SODs}$ were inhibited by cyanide, while Mn-SODs were resistant to cyanide (Fridovich, 1975).

The protein concentration was measured by the method of Bradford (1976), using bovine serum albumin as a standard. Lipid peroxidation products measured at $535 \mathrm{~nm}$ as thiobarbituric acid reactive substances (TBARS) were determined according to Gutteridge (1984). The selenium content in tissues was measured by the fluorimetric method of Rodriguez et al. (1994).

\section{Statistical analysis}

The results are given as means \pm SD of at least three independent determinations in five different batches. Statistical analysis was done by one-way analysis of variance (ANOVA) with the post hoc Tukey multiple comparison test.

\section{RESULTS}

The values of Se and TBARS contents and the activities of GST, GR and CAT in the tissues are given in Table 2. There were significant increases of Se contents in the liver, kidney cortex and heart in both groups supplemented with sodium selenite or Se-yeast when compared with the lambs fed on the basal diet. Significant differences were also found in the livers and hearts of the groups supplemented with selenite and Se-yeast.

GSHPx activity increased only in the group supplemented with selenite in the liver and kidney cortex, while in the heart, GSHPx activity increased in both experimental groups (Figure 1).

GST also exhibits peroxidase activity. This activity was influenced by selenium supplementation in the kidney cortex (decreased) and in the heart (increased) when compared with the control (Table 2).

GR is an enzyme that participates in the metabolic transformation of selenium. Its activity decreased in the liver and kidney cortex in the group supplemented 
Table 2. Effect of different selenium sources in feed of the lambs on some parameters determined in the tissues of liver, kidney cortex and heart

\begin{tabular}{llccccc}
\hline Tissue & Groups & $\begin{array}{c}\mathrm{GST}^{1} \\
\mathrm{U} \cdot \mathrm{mg}^{-1}\end{array}$ & $\begin{array}{c}\mathrm{GR}^{1} \\
\mathrm{U} \cdot \mathrm{mg}^{-1}\end{array}$ & $\begin{array}{c}\text { CAT } \\
\mathrm{U} \cdot \mathrm{mg}^{-1}\end{array}$ & $\begin{array}{c}\text { Se content } \\
\mu \mathrm{mol} \cdot \mathrm{kg}^{-1} \\
\mathrm{DM}\end{array}$ & $\begin{array}{c}\text { TBARS }^{1} \\
\mathrm{~A}_{535} \mathrm{mg}^{-1}\end{array}$ \\
\hline \multirow{3}{*}{ Liver } & Control & $0.9 \pm 0.2$ & $0.039 \pm 0.003^{\mathrm{a}}$ & $1317 \pm 203^{\mathrm{a}}$ & $3.5 \pm 0.9^{\mathrm{a}}$ & $0.027 \pm 0.002^{\mathrm{a}}$ \\
& Selenite & $1.1 \pm 0.2$ & $0.046 \pm 0.008^{\mathrm{a}}$ & $1151 \pm 91^{\mathrm{a}}$ & $22 \pm 2^{\mathrm{b}}$ & $0.021 \pm 0.003^{\mathrm{b}}$ \\
& Se-yeast & $1.0 \pm 0.3$ & $0.026 \pm 0.002^{\mathrm{b}}$ & $997 \pm 39^{\mathrm{b}}$ & $29 \pm 3^{\mathrm{c}}$ & $0.018 \pm 0.002^{\mathrm{b}}$ \\
& & & & & & \\
Kidney & Control & $0.25 \pm 0.01^{\mathrm{a}}$ & $0.075 \pm 0.002^{\mathrm{a}}$ & $183 \pm 12^{\mathrm{a}}$ & $44 \pm 6^{\mathrm{a}}$ & $0.008 \pm 0.003$ \\
& Selenite & $0.22 \pm 0.01^{\mathrm{b}}$ & $0.090 \pm 0.007^{\mathrm{b}}$ & $194 \pm 4^{\mathrm{a}}$ & $85 \pm 14^{\mathrm{b}}$ & $0.008 \pm 0.002$ \\
& Se-yeast & $0.16 \pm 0.03^{\mathrm{c}}$ & $0.063 \pm 0.005^{\mathrm{c}}$ & $122 \pm 15^{\mathrm{b}}$ & $83 \pm 6^{\mathrm{b}}$ & $0.0057 \pm 0.0004$ \\
& & & & & & \\
Heart & Control & $0.20 \pm 0.07^{\mathrm{a}}$ & $0.03 \pm 0.01^{\mathrm{a}}$ & $22 \pm 8^{\mathrm{a}}$ & $2.8 \pm 0.3^{\mathrm{a}}$ & $0.010 \pm 0.001^{\mathrm{a}}$ \\
& Selenite & $0.53 \pm 0.09^{\mathrm{b}}$ & $0.091 \pm 0.008^{\mathrm{b}}$ & $57 \pm 4^{\mathrm{b}}$ & $17 \pm 2^{\mathrm{b}}$ & $0.012 \pm 0.004$ \\
& Se-yeast & $0.66 \pm 0.03^{\mathrm{c}}$ & $0.08 \pm 0.01^{\mathrm{b}}$ & $68 \pm 17^{\mathrm{b}}$ & $20 \pm 2^{\mathrm{c}}$ & $0.016 \pm 0.004^{\mathrm{b}}$ \\
\hline
\end{tabular}

1 per miligrams of protein. Different supersripts within a relevant tissue and parameter mean statistical significance $(\mathrm{P}<0.05)$

GST- glutathione-S-transferase, GR - glutathione reductase, CAT - catalase, TBARS - thiobarbituric acid reactive substances

values are means $\pm \operatorname{SD}(n=5)$

\section{GSHPx}
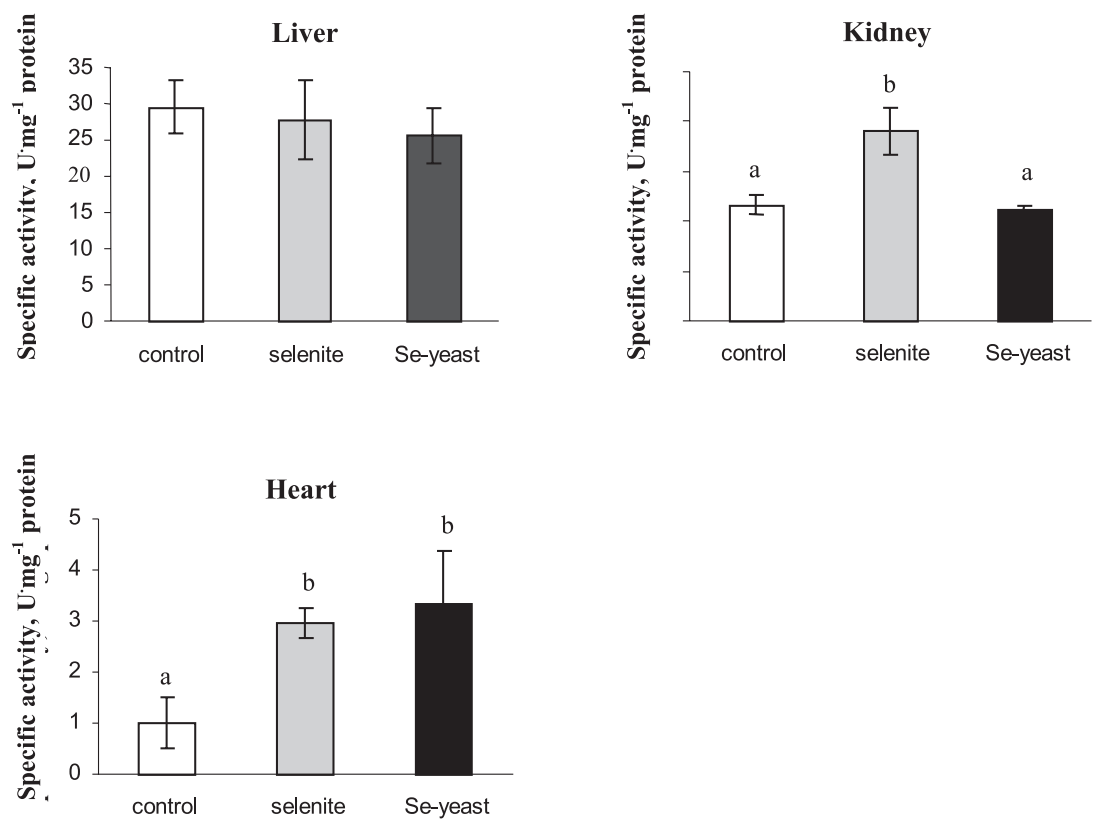

Figure 1. Specific activity of GSHPx in the liver, kidney cortex and heart of the lambs given feed supplemented with various Se-sources. Values are means $\pm \mathrm{SD}(\mathrm{n}=5)$. Distinct letters above columns mean significant differences $(\mathrm{P}<0.05)$ 
with Se-yeast and increased in both selenium-supplemented groups in the heart (Table 2).

We found very high catalase activity in the liver. In the Se-yeast supplemented group the activity of this enzyme significantly decreased in the liver and kidney cortex. In the heart, where catalase activity was relatively low, it increased in both supplemented groups (Table 2).

The activity of SOD was changed only in the kidney cortex and heart after selenium supplementation. In the kidney cortex, SOD significantly increased in the selenite-supplemented group and in the heart tissue of both supplemented groups (Figure 2). Changes in the $\mathrm{Cu}, \mathrm{Zn}-\mathrm{SOD}$ isoenzyme pattern were seen only in the heart in both selenium-supplemented groups (Figure 3). In the selenitesupplemented group, two isoenzyme bands with pI 4.7 and 5.0 were inhibited, whereas in Se-yeast-supplemented group, two bands with pI 5.6 and 6.5 were more intensive.

The TBARS content is a marker of lipid peroxidation. Our results showed no significant changes in TBARS content in the liver and kidney cortex. The TBARS content was, however, significantly higher in heart of lambs fed the diet enriched in Se-yeast (Table 2).

\section{SOD}
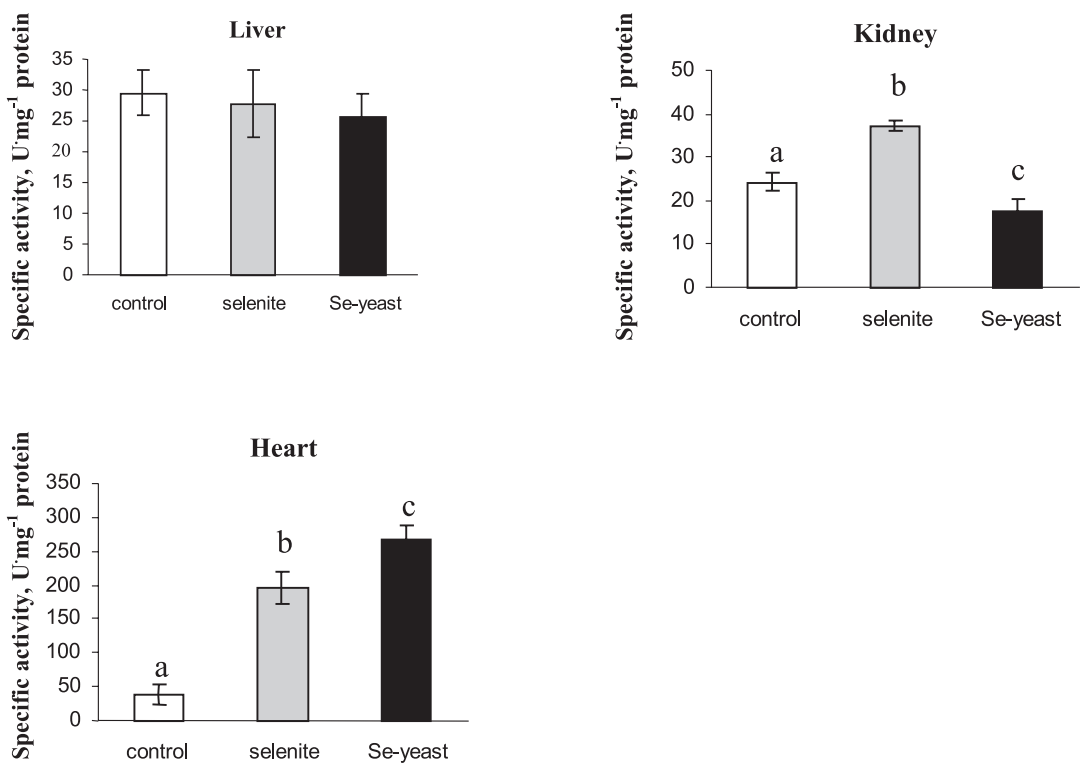

Figure 2. Specific activity of SOD in the liver, kidney cortex and heart of the lambs given feed supplemented with various Se-sources. Values are means $\pm S D(n=5)$. Distinct letters above columns mean significant differences $(\mathrm{P}<0.05)$ 


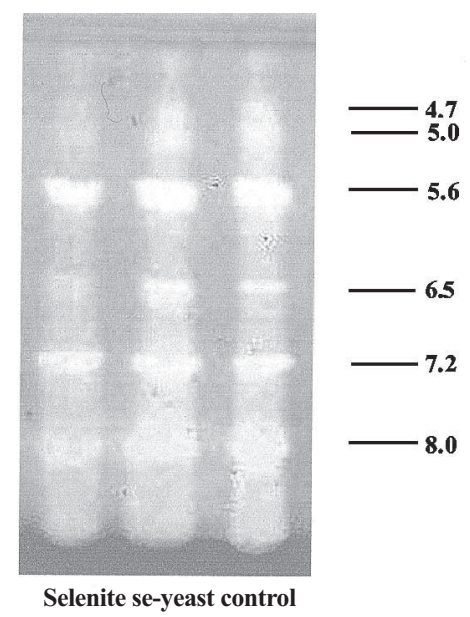

Figure 3. SOD isoenzyme patterns in the tissue extracts of the lamb heart. Zymogram obtained after separation by IEF in an $9.0-3.0 \mathrm{pH}$ gradient. $\mathrm{pI}$ values were determined by using IEF protein marker

\section{DISCUSSION}

Selenium bioavailability has classically been determined by measuring the repletion of tissue selenium concentrations and GSHPx activities in Se-deficient rats (Wen et al., 1997). It has been repeatedly demonstrated that there is a good correlation between selenium tissue accumulation, enzyme activity and selenium status in situations of deficient or marginal selenium supply, whereas the correlation clearly weakens with nutritionally adequate selenium intake (Wolfram, 1999). The intake of organic and inorganic forms of selenium in our experiment was reflected in its increased concentration in the liver, kidney cortex, and heart. To examine the effects of selenium intake in the form of selenite or Se-yeast on selenoenzyme activity in lambs we determined the relative effectiveness of inorganic sodium selenite and organic Se-yeast supplementation in modulating Se-dependent GSHPx activity. This activity significantly increased in the liver and kidney cortex, parenchymal tissues, only in the selenite-supplemented group, while in the Se-yeast group, the activity decreased in the liver or stayed unchanged in the kidney cortex as compared with the control group. The presented results reflect the different metabolism of inorganic and organic forms of selenium. A critical, common intermediate in the metabolism of dietary selenium is hydrogen selenide, which constitutes the socalled "central selenium pool" ( $\mathrm{Li}$ et al., 2004). The precise metabolic route to $\mathrm{H}_{2} \mathrm{Se}$ differs depending on the chemical form of the selenium. Inorganic forms, such as sodium selenite, are metabolized through a multi-step reductive process, which can 
produce a variety of reactive oxygen species, such as superoxide radical anion and hydrogen peroxide (Li et al., 2004). Selenomethionine, found mainly in the Se-yeast supplement, must undergo enzymatic transformation to SeCys before a specific lyase releases selenium without the production of reactive intermediates (Foster et al., 1986). Moreover, a varying part of selenium provided as selenomethionine can be nonspecifically deposited in tissue proteins (Wolfram, 1999). Also, rumen microorganisms can incorporate the selenomethionine from Se-yeast into their own proteins and reduce dietary Se to insoluble forms such as elemental Se that is unavailable for absorption (Hakkarainen, 1993).

The influence of both chemical forms of selenium on the antioxidant enzyme activities in heart muscle tissue was different than in the parenchymal tissues discussed above. It has been reported that the heart is more susceptible to oxidative stress than other organs (Di Meo et al., 1992). Therefore, it is reasonable to suggest that this organ preferentially accumulated Se-dependent antioxidant enzymes. Thus, GSHPx activity significantly increased in the heart of lambs fed diets containing extra selenite or Se-yeast. More intensive metabolism of dietary extra selenite and Se-yeast has been also manifested by increased CAT and SOD activities. Differences in SOD isoenzyme patterns in both supplemented groups indicate possible differential metabolic processing of extra dietary selenium in the heart. It is possible that the two more intensive $\mathrm{Cu}, \mathrm{Zn}$-SOD isoenzyme bands that appeared in the Se-yeast supplemented group were generated as a result of the oxidative stress (Holovská et al., 1996), which also manifested as significantly increased TBARS values.

Our results showed that the response of organs to selenite and Se-yeast supplementation differed and could be related to diverse metabolism of selenium in the particular organs. These results are supported by the work of Bermano et al. (1996) who found that there is different regulation of mRNA and subsequent protein synthesis within and between organs, suggesting that mechanisms exist to channel selenium for the synthesis of particular enzymes in specific tissues.

\section{REFERENCES}

Beauchamp C.O., Fridovich I., 1971. Superoxide dismutase: improved assays and an assay applicable to acryl amide gels. Anal. Biochem. 44, 276-287

Bermano G., Nicol F., Dyer J.A., Sunde R.A., Beckett G.J., Arthur J.R., Hesketh J.E., 1996. Selenoprotein gene expression during selenium-repletion of selenium deficient rats. Biol. Tr. Elem. Res. 51, 211-223

Bradford M.M., 1976. A rapid and sensitive method for the quantification of microgram quantities of protein utilizing the principle of protein-dye binding. Anal. Biochem. 72, 248-254

Di Meo S., Venditti P., De Leo T., 1996. Tissue protection against oxidative stress. Experientia 52, 786-793 
Flohé L., Günzler W.A., 1984. Assays of glutathione peroxidase. Methods Enzymol. 105, 114-121

Flohé L., Ötting F., 1984. Superoxide dismutase assays. Methods Enzymol. 105, 93-104

Foster S.J., Kraus R.J., Ganther H.E., 1986. The metabolism of selenomethionine, Semethylselenocysteine, their selenonium derivatives, and trimethylselenonium in the rat. Arch. Biochem. Biophys. 251, 77-86

Fridovich I., 1975. Superoxide dismutases. Annu. Rev. Biochem. 44, 147-159

Gutteridge J.M.C., 1984. Ferrous ion-EDTA-stimulated phospholipid peroxidation. Biochem. J. 224, 697-701

Habig W.H., Jakoby W.B., 1981. Assays for differentiation of glutathione-S-transferases. Methods Enzymol. 77, 398-405

Hakkarainen J., 1993. Bioavailability of selenium. Norwegian J. Agr. Sci. 11, 21-35

Holovská K., Lenártová V., Pedrajas J.R., Peinado J., López-Barea J., Rosival I., Legáth J., 1996. Superoxide dismutase, glutathione peroxidase and glutathione reductase in sheep organs. Comp. Biochem. Physiol. 115B, 451-456

Li L., Xie Y., El-Sayed W. M., Szakacs J.G., Roberts J.C., 2004. Characteristics of selenazolidine prodrugs of selenocysteine : toxicity, selenium levels, and glutathione peroxidase induction in A/J mice. Life Sci. 75, 447-459

Pinto M.C., Mata A.M., López-Barea J., 1984. Reversible inactivation of Saccharomyces cerevisiae glutathione reductase under reducing conditions. Arch. Biochem. Biophys. 228, 1-12

Rayman M.P., 2004. The use of high-selenium yeast to raise selenium status: how does it measure up? Brit. J. Nutr. 92, 557-573

Reilly C., 1998. Selenium: A new entrant into the functional food arena. Trends Food Sci. Technol. 9, 114-118

Rodriguez E.M., Sanz M.T., Romero C.D., 1994. Critical study of fluorimetric determination of selenium in urine. Talanta 12, 2025-2031

Rotruck J.T., Pope A.L., Ganther H.E., Swanson A.B., Hafeman D.G., Hoekstra W.G., 1973. Selenium: biochemical role as a component of glutathione peroxidase. Science 179, 577-590

Schrauzer G.N., 2000. Selenomethionine: a review of its nutritional significance, metabolism and toxicity. J. Nutr. 130, 1653-1656

Sizer I.W., Beers Jr. R.F., 1952. A spectrofotometric method for measuring the breakdown of hydrogen peroxid by catalase. J. Biol. Chem. 195, 133-139

Wen H.Y., Davis R.L., Shi B., Chen J.J., Chen L., Boylan M., Spallholz J.E., 1997. Bioavailability of selenium from veal, chicken, beef, pork, lamb, flounder, tuna, selenomethionine, and sodium selenite assessed in selenium-deficient rats. Biol. Tr. Elem. Res. 58, 43-53

Wolffram S., 1999. Absorption and metabolism of selenium: differences between inorganic and organic sources. In: T.P. Lyons, K.A. Jacques (Editors). Biotechnology in the Feed Industry. Nottingham University Press, pp. 547-566 